\title{
Opening minds for the wisdom of art
}

\author{
Encounters between art and esotericism
}

DOI: https://doi.org/10.30664/ar.103028

(c)(A) Attribution 4.0 International (CC BY 4.0)

A reflection on the symposium 'Clearsighted Art - Open Mind? Encounters between Art and Esotericism' arranged at the Amos Rex Art Museum, Helsinki, 25th August 2020.

In the ongoing research project 'Seekers of the New', exploring the cultural history of esotericism in the late nineteenth-and early twentieth-century Finland, we analyse artists, writers and musicians in the context of esotericism and related ideas. Our focus is both on the art works and on the lives of these artists, as our aim is to shed light on the various influences that esoteric traditions, movements and ideas have had on culture and society at large. Often we have encountered the topic of the connection between creativity and spirituality: did these artists regard their artistic work as something spiritual or esoteric? Was art a way to discuss spirituality more generally? Moreover, how is it possible to interpret esotericism in art works in the first place?

Many of these questions were discussed at the symposium held in Helsinki in August 2020, organised by the Signe and Ane Gyllenberg Foundation. Our project, and particularly one of its scholars, Nina Kokkinen, took part in organising the symposium. She had already curated an art exhibition for the Villa Gyllenberg Art Museum entitled The Path to Hidden Knowledge. It opened in the early summer of 2020, at a time when we were experiencing the early stages of the global Covid-19 pandemic. Due to restrictions, museums were closed for weeks between March and May. Thus, it was also impossible to organise an opening event. However, early on in the planning of the exhibition, the foundation also decided to host an artistic and academic symposium event to accompany the exhibition. This was held in August late 2020, and, due to the milder restrictions during the summer it was possible arrange securely on-site. The two-day symposium was a combination of an academic workshop at Villa Gyllenberg and a whole day event open to a larger audience. This symposium, which was entitled 'Clear-sighted Art - Open Mind? Encounters between Art and Esotericism' was organised in the beautiful and historical location of the Amos Rex Art Museum's auditorium in the centre of Helsinki.

The programme consisted of presentations, discussions and artistic performances. The day's programme was opened by Nina Kokkinen, who in 2019 defended her $\mathrm{PhD}$ thesis on esotericism in the artistic works of Akseli Gallen-Kallela, Hugo 
Simberg and Pekka Halonen. In her talk, Kokkinen led us through decades of Finnish art works from the late nineteenth century until the mid-twentieth century, and showed the audience how esoteric movements, ideas and currents have been part of the history of Finnish art. Her presentation revealed how this story has not yet been told in all its range. She pointed out how artists and culture at large have seen artistic work as a way of gaining deeper knowledge of ourselves and of the world surrounding us (see Kokkinen in this issue). Kokkinen's talk was followed by a response from the director of the Amos Anderson Museum, Kai Kartio. The most intriguing part of his commentary was an autobiographical memory of his grandmother, who had been a devoted Theosophist. Kartio pointed out how her devotion opens up in a new light as research on the cultural history of esotericism is now being done. Kartio's musings articulate the overall significance of the present discussions and research on the traditions of esotericism in the cultural history of Finland. Up until now, this history has been quite marginalised and undiscussed, and it has not been part of our shared past. Now that research is ongoing from new perspectives, and open symposia like this are being organised, many people whose lives have been part of the history of esotericism feel a certain kind of relief. They are finally able to talk about and share their history with other people.

A similar kind of openness was in the air as I sat down with two artists to discuss the meanings of spirituality, esotericism and mysticism in their art and in their work. The writer Heikki Kännö and the artist Hannaleena Heiska openly shared their ideas on creativity, art and esotericism. Kännö and Heiska talked about their ideas on the processes of making art and being an artist in contemporary society.

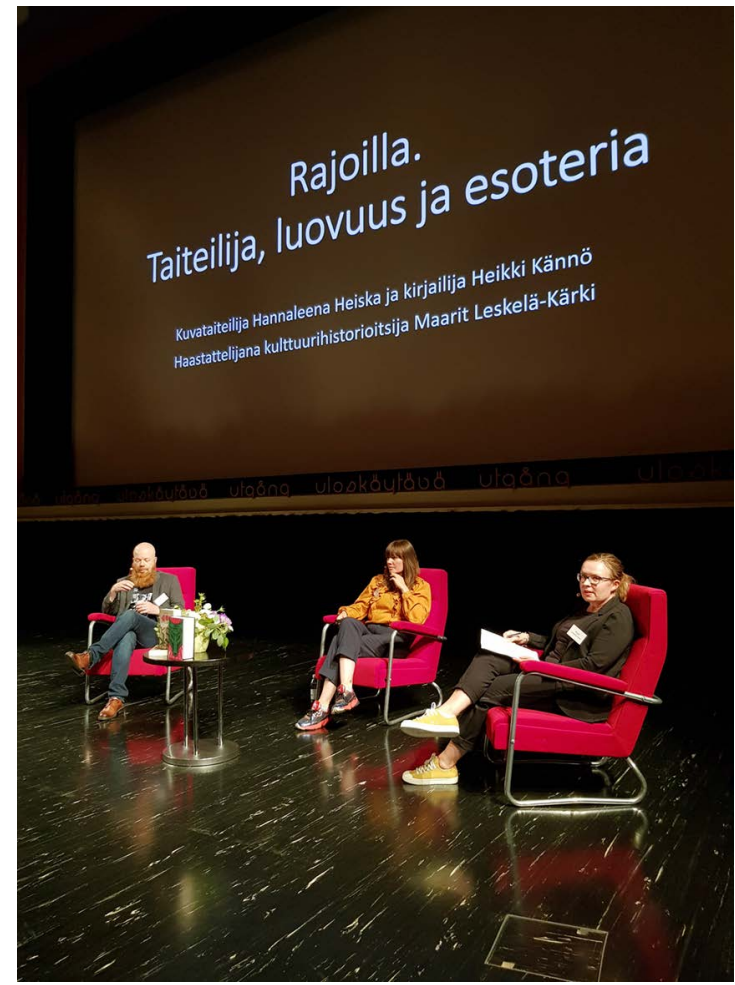

The author Heikki Kännö and the artist Hannaleena Heiska in conversation with Maarit Leskelä-Kärki. Photo: Nina Kokkinen.

Kännö is known for his lengthy novels that gain inspiration from the cultural history of Europe, and often use rich literary source material related to the history of esotericism. His latest novel, for example, Runoilija ('Poet'), deals with Rudolf Steiner and Anthroposophy. Hannaleena Heiska sees art as taking part in the discussions concerning the future of humankind, and although her art work is not societal in a narrow sense, she wants to take part in societal discussions. Her artwork Something There Is deals with stardust, planets and the universe, and she uses coal - organic material that is the basis of our being:

Coal is an organic element and part of the cycle of life. I am intrigued by the idea that we are made of stardust, and life is based on coal atoms. Charcoal 
often feels like dust, it melts into fragile particles. In my art, observatories symbolize our observation into the birth of the universe: what we are and where do we come from? (Heiska 2018)

The artistic discussion was followed by a ritual art performance directed by JaniPetteri Olkkonen and performed by Ilona Keňová. The auditorium sat silent as the stage changed into a mystic interweaving of music, dance and lights.

The last talk of the day was given by the artist Jan-Olof Mallander, who took us through his artistic career from the 1960 s onwards with autobiographical memories and pictures of his work. As a musician and painter, Mallander has been one of the central avant-garde artists of post-war Finland, and he has openly been inspired by Eastern mysticism, and particularly Buddhism. As a committed Buddhist he sees himself as a seeker who has been inspired by Zen Buddhism and, for example, the artist John Cage's ideas. He has not only made art himself but has also collected a wide collection of Eastern art (Sepp 2020). Mallander's autobiographical talk was followed by a commentary and discussion with the art historian Riikka Stewen.

The closing of the symposium brought together many decades of Finnish cultural and art history that has been inspired by various spiritual and esoteric flows. It also

* Finnish original: 'Hiili on orgaaninen alkuaine ja osa kiertokulkua. Minua kiehtoo ajatus, että meidät ihmiset on tehty tähtipölystä, ja elämä perustuu hiiliatomeihin. Piirustushiili myös tuntuu pölyltä, se murenee hauraiksi hiukkasiksi. Observatoriot töissäni symboloivat tähystystä maailmankaikkeuden synnyn alkuun: mitä me olemme ja mistä me tulemme?' (Heiska 2018, my translation).

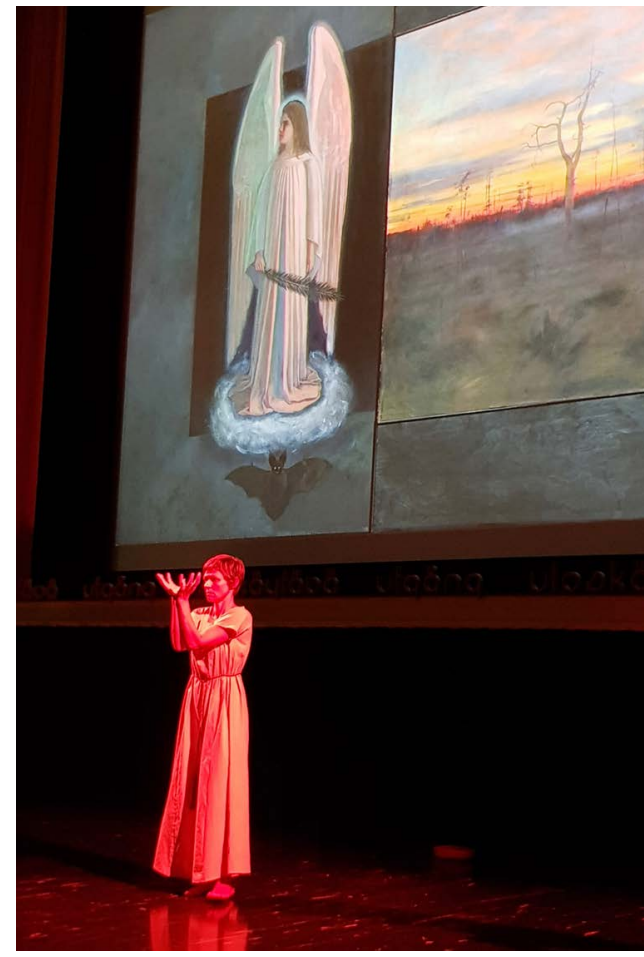

A ritual art performance directed by JaniPetteri Olkkonen and performed by Ilona Keňová. Photo: Nina Kokkinen.

pointed out that there is a lot research to be done in the future in order to gain a richer and fuller view of the various traditions that have influenced our art and culture. Based on the lively and open discussion, it was easy to gather how interested the audience - consisting of artists, art students, Theosophists, scholars and others - was in joining in the discussion of this part of our cultural history.

Maarit Leskelä-Kärki, PhD, Adjunct Professor, is a Senior Lecturer at the Department of Cultural History at the University of Turku. She is also the co-director of the research center SELMA: Centre for

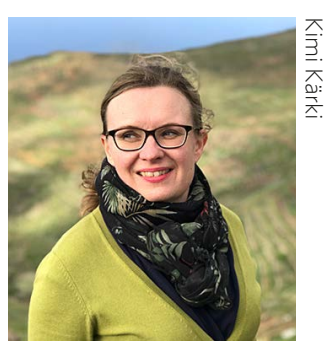
the Study of Storytelling, Experientiality and Memory. Leskelä-Kärki's main research interests 
cover cultural history of women's writing, life writing studies and cultural history of religiosity. She is the leader of the research project 'Seekers of the New: Esotericism and the Transformation of Religiosity in the Modernising Finland, 18801930'.

\section{References}

Heiska, Hannaleena. 2018. 'Kuvataiteilija Hannaleena Heiska: "Meidät ihmiset on tehty tähtipölystä”, Deko, 10/2018, <https:// kotiliesi.fi/deko/kuvataiteilija-hannaleenaheiska-meidat-ihmiset-on-tehty-tahtipolysta/> (accessed 3.11.2020).

Seppänen, Arttu. 2020: 'Taiteilija J. O. Mallander on etsinyt totuutta 1960-luvulta alkaen niin buddhalaisuuden kuin silkan sekoilunkin kautta, Helsingin Sanomat, 3.11.2020, <https://www.hs.fi/kulttuuri/art-2000006708627.html> (accessed 25.2.2021). 